\title{
SPATIO-TEMPORAL STUDY OF DIAGNOSIS OF RABIES IN VAMPIRE BATS IN SERGIPE (BRAZIL), BETWEEN 1987 AND 2014
}

\author{
ESTUDO ESPAÇO-TEMPORAL DE DIAGNÓSTICOS DA RAIVA EM MORCEGOS \\ HEMATÓFAGOS EM SERGIPE (BRASIL), ENTRE 1987 E 2014.
}

\begin{abstract}
Karla Dias ANTUNES ${ }^{\mathbf{1}}$; Tiago Mendonça de OLIVEIRA ${ }^{\mathbf{1}}$; Júlya Cunha de Carvalho MATOS ${ }^{\mathbf{1}}$; Soraia de Araújo DINIZ ${ }^{1}$; Thiago Luiz Mendes ARCEBISPO ${ }^{1}$; Tales Bernardes da SILVA ${ }^{1}$; Célio da Cruz FONTES ${ }^{2}$; Carlos Henrique Lordelo dos REIS ${ }^{3}$; Marcos Xavier SILVA ${ }^{1}$

1. Escola de Veterinária da Universidade Federal de Minas Gerais, Belo Horizonte, MG, Brasil. marcosxavier@ufmg.br; 2. Empresa de Desenvolvimento Agropecuário de Sergipe, Nossa Senhora do Socorro, SE, Brasil; 3. Laboratório Central da Fundação de Saúde Parreiras Horta, Aracaju, SE, Brasil.
\end{abstract}

\begin{abstract}
Rabies is a zoonosis of great importance for human and animal health, being responsible for a progressive and acute encephalitis in humans and animals. Considering that the correct viral identification has serious implications for the prophylaxis and treatment, is important a diagnostic system specifically designed for monitoring the infection cases. The objective of the study was to describe the occurrence of rabies in hematophagous bats (Desmodus rotundus) analyzing many diagnoses performed in the state of Sergipe. The objective of this study was to describe the occurrence of rabies in hematophagous bats (Desmodus rotundus) from an analysis of the diagnoses performed in the state of Sergipe. An observational, descriptive and retrospective study was conducted with the evaluation of 935 rabies diagnoses in bats (D. rotundus) between 1987 and 2014. It was noticed that only one case was positive in the city of Aracaju in the year 2000 and no positive bat was identified with the rabies virus in the rural area. The results show the need to increase the monitoring of rabies in other species of non-hematophagous bats, and especially in other wild reservoirs. It is suggested that the monitoring of rabies take into account the specific ecosystem of each region, since Brazil has continental dimensions and a great biological diversity.
\end{abstract}

KEYWORDS: Epidemiology. Monitoring of rabies. Desmodus rotundus.

\section{INTRODUCTION}

According with World Organization for Animal Health (OIE, 2014), rabies is an important zoonosis, responsible for 70.000 deaths per year over the world, most of them children in developing countries. Is caused by a RNA virus of the genus Lyssavirus and of family Rhabdoviridae with seven different genotypes (GOULD et al., 1998, FAVORETTO et al., 2013).

Several studies upon rabies disease have been performed over the time, but the monitoring of this zoonosis is still of fundamental importance, since it is a mandatory notification disease. The outcome of the constant changes in the agroecosystem and in urban areas contribute to the emergence of new aspects of the rabies cycle, favoring the presence of new positive reservoirs, in addition to increasing the risk's potential of the transmission for the domestic animals (KOTAIT et al., 2007).

The OIE (2014) provides a scientific basis for norms, guidelines, and recommendations for disease control in animals in order to prevent their dissemination, as well as patterns for the diagnosis of rabies and the production of high-quality veterinary vaccines.

Bats play an important role in cycle of this disease and are possible natural reservoirs and/or transmitters of the virus. The transmission of rabies virus was suggested at the beginning of the last century by Carini (1911) when studying an epizootic in Santa Catarina - Brazil. The bat Desmodus rotundus is the most abundant species in regions of livestock ranching, several Latin American countries have developed programs for their control, since the vaccination of domestic animals does not prevent the occurrence of spoliation, nor the spread of the virus among populations wild (MAPA, 2009).

Is relevant know the infectious diseases epidemiological models, such as of rabies, for understand the spatial organization, the anthropic alterations, in order to remodel news habitats of possible vectors, hosts or reservoirs, assessing the transmission risk and observing occurrence of outbreaks of diseases. Recently, in the state of Mato Grosso do Sul - Brazil, on September, 6, 2014, it was reported by the Municipal Health Secretariat (SMS) of Corumbá an outbreak of rabie bovine, 
canine and human. It is observed that Brazil still has the disease in an endemic status over the populations of different regions, being that human cases are found in urban areas after outbreaks in dogs (FAVORETTO et al., 2013). The cases of human and animal rabies outbreaks such as the above strengthens the premise that this disease should be researched, monitored, discussed and updated. Carnivores and bats are reservoirs and a major source of infection for men and domestic animals. Nevertheless, has been described in Brazil a wild cycle and a terrestrial cycle in outbreaks and occurrences (KOTAIT et al., 2009, FAVORETTO et al., 2013, ANTUNES et al., 2018).

Rural rabies remains current as a result of bats $D$. rotundus maintaining of rabies in bovines and, and recently, responsible for outbreaks of the disease in humans (RUPPRECHT et al., 2002, SCHNEIDER et al., 2009, KOTAIT et al., 2010, FAVORETTO et al., 2013).

The herbivores have an importance of sentinels (SCHNEIDER et al., 2009) for a virus presence to human populations. The Ministry of Agriculture and Livestock (MAPA) recommends the vaccination of herds and monitoring of bloodsucking bats as prevention and control measures of rabies (MAPA, 2009, DIAS et al., 2011, BRAGA et al., 2014).

Therefore, this research aimed to describe the occurrence of rabies in hematophagous bats from the diagnoses carried out in the state of Sergipe from 1987 to 2014 by the state's animal health surveillance service, totaling 27 years of surveillance.

\section{MATERIAL AND METHODS}

An observational, descriptive and retrospective study was carried out on the diagnosis of rabies in bats (D. rotundus) in the state of Sergipe between 1987 and 2014. Localized in the brazilian northeast region, with an area of $21,918,493 \mathrm{~km}^{2}$, it is corresponding to $0,26 \%$ of the national territory, and it is constituted by 75 municipalities and three mesoregions (Agreste Sergipano composed of 18 municipalities, East Sergipano with 42 municipalities and Sertão Sergipano with 15 municipalities).

It was performed a description the frequencies of the number of samples of hematophagous bats sent to the Central Laboratory of Parreiras Horta Health Foundation (LACEN) of the state of Sergipe. Addition, assessed the spatial distribution of the samples was performed in order to identify the trend of the occurrence of the diagnoses negative and positive. There was a fragmentation of the historical series in four periods $(1980 \mathrm{~s}, 90 \mathrm{~s}, 2000 \mathrm{~s}$ and the period from 2010 to 2014), in which the results for rabies in the studied species they were estimated for a better understanding of the data. The software QGIS 2.18.14 was used to describe the spatial distribution of the results.

In order to describe the rabies cases distribution in hematophagous bats, 935 immunodiagnostic and biological tests were analyzed. All laboratory diagnosis was performed at the Central Laboratory - (LACEN), in the Sergipe Agricultural Development Company (EMDAGRO), as of reported suspect cases. The diagnoses were performed through two techniques, the Direct Immunofluorescence (IFD) and of Intracerebral Inoculation in Mice (IICC) during the study period.

\section{RESULTS}

Among the 935 results obtained in hematophagous bats, 926 were considered negative and one positive case, in addition, two cases were discarded due to the transcript failure to fill the forms, five results were classified as ignored and one inconclusive result (Table 1). It was observed that in the period from 2000 to 2009 there was a considerable increase of diagnoses for rabies in hematophagous bats, with 550 more exams compared to the previous period.

Table 1. Diagnosis of rabies in hematophagous bats from 1987 to 2014 in the State of Sergipe, Brazil.

\begin{tabular}{l|c|c|c|c}
\hline \multirow{2}{*}{ Period } & \multicolumn{4}{|c}{ Hematophagous bats } \\
\cline { 2 - 5 } & Pos. & Neg. & Inc. & Ign. \\
\hline Before 90's & 0 & 19 & 0 & 0 \\
\hline 1990 to 1999 & 0 & 15 & 0 & 0 \\
\hline 2000 to 2009 & 1 & 565 & 1 & 5 \\
2010 to 2014 & 0 & 327 & 0 & 0 \\
\hline
\end{tabular}

Legend: Pos.= Positive; Neg.= Negative; Inc. = Inconclusive; Ign = Ignored. 
Figure 1 shows many rabies exams in hematophagous bats in state of Sergipe, between 1987 and 2014. It was not possible to find spatiotemporal clustering areas with the data, suggesting other important reservoirs for disease maintenance in environments wild, such as other hematophagous bats, wild animals such as crabeating fox and primates.
ANTUNES, K. D. et al.

In the descriptive analysis of data was verified that in brazilian city of Aracaju, in the year 2000 , there was the presence of six inconclusive or ignored results, only one case has a positive result, which demonstrates the central importance of bats in the rabies urban cycle in Sergipe (Figure 1).

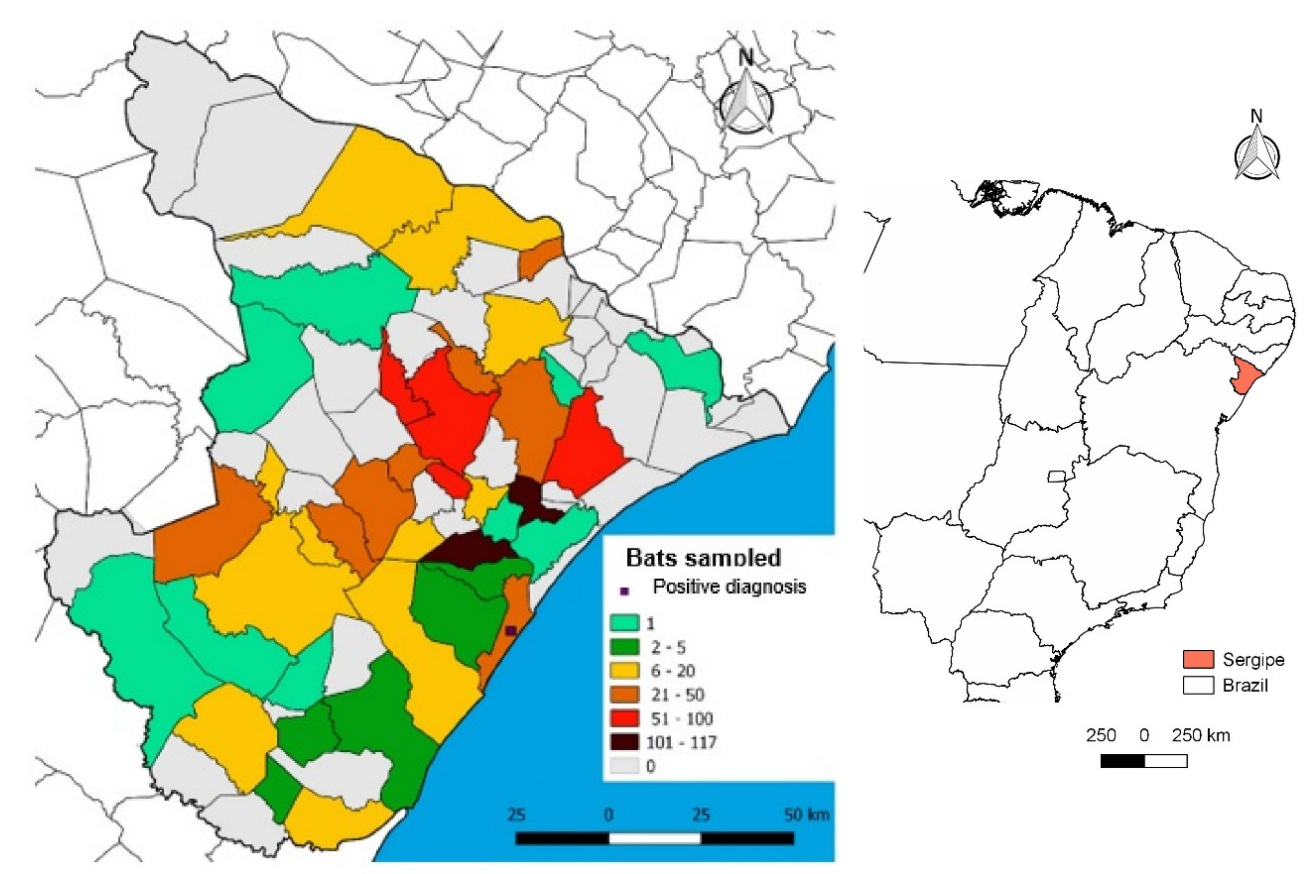

Figure 1. Spatial distribution of negative and positive results of rabies in hematophagous bats in the state of Sergipe Brazil, between 1987 and 2014.

\section{DISCUSSION}

Based on the data analyzed was verified that only one case was positive for rabies in the city of Aracaju in 2000, although they have not been identified positive vampire bats in rural areas. It was not possible assign bats $D$. rotundus the risk of disease transmission since the sampling carried out by the official service may no longer contemplate the populations at risk for the disease, due some bat colonies are in areas of difficult access and close contact with cattle herds. The difficulty of reaching the shelters of hematophagous bats is also reported by Dias et al. (2011), which recognize the efforts of public agencies to carry out the registration and typification these shelters, however, they discuss the difficulty of performing this task mainly in the remnants of natural forests. According to Queiroz et al. (2012), a recent change in the rabies virus life cycle has placed the bats as a prominent actor in the epidemiological urban persistence of the rabies virus. These modifications expose a hematophagous bats adaptation and demonstrate the aerial urban alteration becoming the main actor of the terrestrial viral infection, in substitution of the dog as the main actor.

The recent bat's compliance to the urban areas indicates an important and necessary updating of the actual rabies control programme adopted by the Brazilian government, it refers especially be concerning among the herbivores species, since the research of the virus presence in hematophagous bats may no longer be sufficient and efficiently in the viruses monitoring of the disease in the rural environment. Studies have already demonstrated the presence of rabies virus in non-hematophagous bats, as observed by Albas et al. (2005), that detected the presence of 74 positive samples, of which $58(78.4 \%)$ were non-hematophagous bats in the region of Presidente Prudente, SP, in period 1996 to 2003. In their study Casagrande et al. (2014) found that the hematophagous bats did not have the virus, but the antibodies, while the nonhematophagous bats were those that had the 
circulating virus, proving once again that nonhematophagous bats are important for the maintenance of rabies in the environment. Despite observing only a positive diagnosis for rabies in bats D. rotundus in the state of Sergipe, it is important to consider rabies exams in other species such as the cattle. These production animals can be used for monitoring the viral circulation and the adoption of prevention and control measures, since the transmission of the virus to these species occurs mainly by the bite of the blood-sucking bats.

Over time the state of Sergipe increased the number of samples analyzed, this type of epidemiological surveillance for rabies is useful in the prevention and detection of cases of the disease in urban and rural areas. For Carnieli et al. (2006), municipalities that send samples regularly have found high rates of positivity, demonstrating the importance of this surveillance as a sentinel for adopting measures of control and prevent human cases. The rabies transmitted by bats depends basically on the presence of the virus in the population of susceptible mammals and not just the number of attacks by them. In the Brazilian northeast, it can realize that most of the attacks occur during the dry season when the farmers take their herds to areas of natural forest. Thus these producers they are exposed to risk, with the possibility of outbreaks in humans. The bats have been responsible for $70 \%$ of human rabies cases over the last decade (2004-2013) in Brazil, according to the Pan American Health Organization (2014).

Some reports of rabies cases in demonstrate the infection in any wild mammal, increasing concerns according to Brasil (2017), although phylogenetic studies and epidemiological surveillance schemes revealed possible reservoirs of rabies, such as insectivorous bats (SODRÉ et al., 2010), canine (CARNIELI et al., 2008; VelascoVilla et al., 2008), horses (FAVORETTO et al., 2002, QUEIROZ et al., 2012) and deer (PETERSEN et al., 2012). This can be explained because in the ecosystem, one or more species of mammals can transmit the rabies virus, in addition to which these animals can be found in the same habitat.

Areas of spatiotemporal clustering of the diagnoses for rabies were not observed, since only one positive case was reported during the study period. This result shows low circulation of the rabies virus in bats $D$. rotundus, but does not rule out the presence of the virus in other species of bats. In the state of São Paulo Albas et al. (2011) observed the presence of rabies virus in species of non-hematophagous bats belonging to the families
Phyllostomidae and Vespertilionidae, reinforcing the idea that the virus may be disseminated between non-hematophagous bats and hematophagous, considering that they may cohabit close environments.

It is important to carry out the diagnosis for rabies in other species of non-hematophagous bats, since some studies have shown that insectivorous and frugivorous species can contribute to the rabies cycle as demonstrated by Queiroz et al. (2009), which found $70 \%$ of insectivorous bats contaminated with the virus and $30 \%$ in frugivores in the northwest region of São Paulo, and no cases were recorded in a hematophagous bat in Presidente Prudente, SP. Another study also carried out in the state of São Paulo, Scheffer et al. (2007), the indexes of positive diagnoses for rabies were low of $1.9 \%$ (82/4.393), being $1.4 \%(6 / 415)$ for bats hematophagous and $1.9 \%$ (76/3.978) for nonhematophagous. These studies reinforce the idea of a wider diagnosis in the species of bats.

\section{CONCLUSIONS}

It was observed only one positive diagnosis for rabies in hematophagous bats, however, this type of research is still necessary for monitoring rabies and so decrease the risks of the disease transmission in animals and humans. Between the years 2000 and 2014 there was an increase in the number of diagnoses, what could demonstrate the importance of disease as zoonosis, besides show that the state of Sergipe intensified the active search by virus.

Is important consider other wild reservoirs in the rabies cycle, besides increasing monitoring of wild and domestic species makes it possible to mitigate the risks of entering and maintaining the virus in the environment. The monitoring of rabies must be extended to other species of nonhematophagous bats considering that in recent years it has gained an important role as a maintainer and disseminator of rabies virus, due to the modification of the epidemiological cycle of this disease in urban environments. The absence of the identification of hematophagous bats positive cases for rabies, in rural areas, indicates the importance of other wild reservoirs, since the disease is present in cattle.

An improvement in the official surveillance service of animal rabies can be considered an investment in public health, due to the importance that this zoonosis still has in the present times. Therefore, it is necessary to expand the search for non-hematophagous bats and other wild species for Rabies Control and Monitoring in Brazil. It is suggested that the monitoring of rabies take into 
account the specific ecosystem of each region, since Brazil has continental dimensions and a great biological diversity.

\section{ACKNOWLEDGEMENTS}

This research was funded by National Council for Scientific and Technological Development (CNPq) and by the Minas Gerais State Research Foundation (FAPEMIG).

RESUMO: A raiva é uma zoonose de grande importância para a saúde humana e animal, sendo responsável por uma encefalite progressiva e aguda em humanos e animais. Considerando que a correta identificação viral tem sérias implicações para a profilaxia e tratamento, é importante um sistema de diagnóstico especificamente projetado para monitorar os casos de infecção. O estudo teve como objetivo descrever a ocorrência da raiva em morcegos hematófagos (Desmodus rotundus) a partir da análise dos diagnósticos realizados no estado de Sergipe. Foi realizado um estudo observacional, descritivo e retrospectivo com avaliação de 935 diagnósticos de raiva em morcegos (D. rotundus) entre os anos de 1987 a 2014. Percebeu-se que apenas um caso foi positivo na cidade de Aracaju no ano 2000 e nenhum morcego positivo foi identificado com o vírus da raiva na área rural. Os resultados demonstram a necessidade de ampliar o monitoramento da raiva em outras espécies de morcegos não hematófagos e sobretudo em outros reservatórios selvagens. Sugere-se que o monitoramento da raiva leve em consideração o ecossistema específico de cada região brasileira, já que o Brasil tem dimensões continentais e uma grande diversidade biológica.

PALAVRAS-CHAVE: Epidemiologia. Monitoramento da raiva. Desmodus rotundus.

\section{REFERENCES}

ALBAS, A.; ZOCOLARO P. T.; ROSA, T. Z.; CUNHA, S. E. M. Diagnóstico laboratorial da raiva na região oeste do Estado de São Paulo. Revista da Sociedade Brasileira de Medicina Tropical, v. 38, n. 6, p. 493-495, 2005. https://doi.org/10.1590/S0037-86822005000600009

ALBAS, A.; SOUZA, E. A. N.; PICOLO, M. R.; FAVORETTO, S.R.; GAMA, A. R.; SODRÉ, M. M. Os morcegos e a raiva na região oeste do Estado de São Paulo. Revista da Sociedade Brasileira de Medicina Tropical, v. 44, n. 2, p. 201-205, 2011. https://doi.org/10.1590/S0037-86822011005000001

ANTUNES, K. D.; MATOS, J. C. C.; MOL, L. P.; OLIVEIRA, M. A.; ARCEBISPO, T. L. M.; SANTOS, V. G.; OLIVEIRA, T. M.; FONTES, C. C.; REIS, C. H. L.; DINIZ, S. A.; PEREIRA, P. L. L.; SILVA, M. X. Descriptive analysis of rabies in wild animals in the state of Sergipe, Brazil. Arquivo Brasileiro de Medicina Veterinária e Zootecnia, v. 70, n. 1, p. 169-173, 2018. https://doi.org/10.1590/1678-4162-9574

BRAGA, G. B.; GRISI-FILHO, J. H. H.; LEITE, B. M.; SENA, E. F. de; DIAS, R. A. Predictive qualitative risk model of bovine rabies occurrence in Brazil. Preventive Veterinary Medicine, v. 113, n. 4, p. 536-546, 2014. https://doi.org/10.1016/j.prevetmed.2013.12.011

BRASIL. Ministério da Saúde (MS). Guia de vigilância epidemiológica Brasília: MS - $2^{\circ}$ ed., p. 600-625, 2017.

CARINI, A. Sur une grande épizootie de rage. Annales De l'Institut Pasteur, v. 25, p. 843-846, 1911.

CARNIELI, P. J. R.; BRANDÃO, P. E.; CARRIERI M. L.; CASTILHO, J. G.; MACEDO, C. I.; MACHADO, L. M.; RANGEL, N.; CARVALHO, R. C.; CARVALHO, V. A.; MONTEBELlO, L.; WADA, M.; KOTAIT, I. Molecular epidemiology of rabies virus strains isolatedfrom wild canids in Northeastern Brazil. Virus

Research, v. 120, p. 113-120, 2006. https://doi.org/10.1016/j.virusres.2006.02.007 
CARNIELI, P. J. R.; FAHL, W.de O.; CASTILHO, J. G.; OLIVEIRA, R.de N.; MACEDO, C. I.; DURYMANOVA, E.; JORGE R. S.; MORATO, R. G.; SPÍNDOLA, R. O.; MACHADO, L. M.; UNGAR, de SÁ J. E.; CARRIERI, M. L.; KOTAIT, I. Characterization of Rabies virus isolated from canids and identification of the main wild canid host in Northeastern Brazil. Virus Research, v. 131, n. 1, p. 33-46, 2008. https://doi.org/10.1016/j.virusres.2007.08.007

CASAGRANDE, D. K. A.; FAVARO, A. B. B. de B. da C.; CARVALHO, C. D. E.; PICOLO, M. R.; HERNANDEZ, J. C. B.; LOT, M. S.; ALBAS, A.; ARAÚJO, D. B.; PEDRO, W. A.; QUEIROZ, L. H. Rabies surveillance in bats in Northwestern State of São Paulo. Revista da Sociedade Brasileira de Medicina Tropical, v. 47, n. 6, p. 709-715, 2014. https://doi.org/10.1590/0037-8682-0189-2014

DIAS, R. A.; NOGUEIRA-FILHO, V.de S.; GOULART, C. da S.; TELLES, I. C. O.; MARQUES, G. H. F.; FERREIRA, F.; AMAKU, M.; FERREIRA-NETO, J.S. Modelo de risco para circulação do vírus da raiva em herbívoros no Estado de São Paulo Brasil. Pan American Journal of Public Health, v. 30, n. 4, p. 370-376, 2011.

FAVORETTO, S. R.; CARRIERI, M. L.; CUNHA, E. M. S.; AGUIAR, E. A. C.; SILVA, L. H. Q.; SODRÉ, M. M.; SOUZA, M. C.; KOTAIT, I. Antigenic typing of Brazilian rabies virus samples isolated from animals and humans, 1989-2000. Revista do Instituto de Medicina Tropical de São Paulo, v. 44, p. 91-95, 2002. https://doi.org/10.1590/S0036-46652002000200007

FAVORETTO, S. R.; MATTOS, C. C.de; MATTOS, C. A.de; CAMPOS, A. C. A.; SACRAMENTO, D. R. V.; DURIGON, E.L. The emergence of wildlife species as a source of human rabies infection in Brazil. Epidemiology and Infection, v. 141, p. 1552-1561, 2013. https://doi.org/10.1017/S0950268813000198

GOULD, A. R.; HYATT, A. D.; LUNT, R.; KATTENBELT, J. A.; HENGSTBERGER, S.; BLACKSELL, S. D. Characterisation of a novel lyssavirus isolated from Pteropid bats in Australia. Virus Research, v. 54, n. 2, p. 165-187, 1998. https://doi.org/10.1016/S0168-1702(98)00025-2

GONÇALVES, M. A. S.; SÁ-NETO, R. J.; BRAZIL, T. K. Outbreak of aggressions and transmission of rabies in human beings by vampire bats in northeastern Brazil. Revista da Sociedade Brasileira de Medicina Tropical, v. 35, n. 5, p. 461-464, 2002. https://doi.org/10.1590/S0037-86822002000500006

HILL, R. E. JR.; BERAN, G. W.; CLARCK, W. R. Demonstration of rabies vírus-specific antibody in the sera of free-ranging Iowa raccoons (Procyon lotor). Journal of Wildlife Diseases, v. 28, n. 3, p. 377-385, 1992. https://doi.org/10.7589/0090-3558-28.3.377

KOTAIT, I.; CARRIERI, M. L.; CARNIELI, P. J. R.; CASTILHO, J. G.; OLIVEIRA, R. de N.; MACEDO, C. I.; FERREIRA, K. C. S.; ACHKAR, S.M. Reservatórios silvestres do vírus da raiva: um desafio para a saúde pública. BEPA. Boletim Epidemiológico Paulista, v. 4, n. 40, p. 1-9, 2007.

KOTAIT, I.; CARRIERI, M. L.; TAKAOKA, N. Y. Raiva, aspectos gerais e clínica. Manual técnico do Instituto Pasteur, Instituto Pasteur: São Paulo; 2009. n. 8, 49p.

KOTAIT, I.; NOGUEIRA-FILHO, V. S.; SOUZA, M. C. A. M.; CARRIERI, M. L.; GOMES, M. N.; PERES, N. F. Manual de Controle da Raiva dos Herbívoros. São Paulo, Instituto Pasteur (Manuais, 9); 2010. 58p.

MAPA, Ministério da Agricultura, Pecuária e Abastecimento. Controle da Raiva dos herbívoros: manual técnico 2009. Brasília: MAPA/DAS/ACS; 2009. 124 p.

OIE. No more deaths from rabies. World Organization for Animal Health. 2014.

Disponível em: <Available at: http://www.oie.int/en/for-the-media/editorials/detail/article/no-moredeaths-fromrabies/\#_ftn1> Acesso em 12 jan. 2017. 
Organização Panamericana Da Saúde, Organização Mundial da Saúde. Sistema de informação epidemiológica, database 2014, históricos anuais [Internet]. [Cited 2014 April 03]. Disponível em:

$<\mathrm{http} / / /$ siepi2.panaftosa.org.br/Export.aspx/.> Acesso em 10 fev. 2017.

PETERSEN, B. W.; TACK, D. M.; LONGENBERGER, A.; SIMEONE, A.; MOLL, M. E.; DEASY, M. P.; BLANTON, J. D.; RUPPRECHT, C. E. Rabies in Captive Deer, Pennsylvania, USA, 2007-2010. Emerging Infectious Diseases, v. 18, n. 1, p. 138-141, 2012. https://doi.org/10.3201/eid1801.111189

QUEIROZ, L. H.; CARVALHO, C.; BUSO, D. S.; FERRARI, C. I. L.; PEDRO, W. A. Perfil epidemiológico da raiva na região Noroeste do Estado de São Paulo no período de 1993 a 2007. Revista da Sociedade

Brasileira de Medicina Tropical, v. 42, p. 9-14, 2009. https://doi.org/10.1590/S0037-86822009000100003

QUEIROZ, L. H.; FAVORETTO, S. R.; CUNHA, E. M. S.; CAMPOS, A. C.; LOPES, M. C., de CARVALHO, C.; IAMAMOTO, K; ARAÚJO, D. B.; VENDITTI, L. L.; RIBEIRO, E. S.; PEDRO, W. A.; DURIGON, E. L. Rabies in southeast Brazil: a change in the epidemiological pattern. Archives of Virology, v. 157, p. 93-105, 2012. https://doi.org/10.1007/s00705-011-1146-1

RUPPRECHT, C. E.; HANLON, C. A.; HEMACHUDHA, T. Rabies re-examined. The Lancet Infectious Diseases, v. 2, n. 6, p. 327-343, 2002. https://doi.org/10.1016/S1473-3099(02)00287-6

SCHEFFER, K. C.; CARRIERI, M. L.; ALBAS, A.; SANTOS, H. C. P.; KOTAIT, I.; ITO, F. H. Vírus da raiva em quirópteros naturalmente infectados no Estado de São Paulo, Brasil. Revista de Saúde Pública, v. 41, p. 389-395, 2007. https://doi.org/10.1590/S0034-89102007000300010

SCHNEIDER, M. C.; ROMIJN, P. C.; UIEDA, W.; TAMAYO, H.; da SILVA, F.; BELOTTO, A.; da SILVA, J. B., LEANES, L.F. Rabies transmitted by vampire bats to humans: An emerging zoonotic disease in Latin America? Pan American Journal of Public Health, v. 25, v. 3, p. 260-269, 2009.

SODRÉ, M. M.; da GAMA, A. R.; de ALMEIDA, M. F. Updated list of bat species positive for rabies in Brazil. Revista do Instituto de Medicina Tropical de São Paulo, v. 52, n. 2, p. 75-81, 2010. https://doi.org/10.1590/S0036-46652010000200003

VELASCO-VILLA, A.; REEDER, S. A.; ORCIARI, L. A.; YAGER, P. A.; FRANKA, R.; BLANTON, J. D.; ZUCKERO, L.; HUNT, P.; OERTLI, E. H.; ROBINSON, L. E.; RUPPRECHT, C. E. Enzootic rabies elimination from dogs and reemergence in wild terrestrial carnivores, United States. Emerging Infectious Diseases, v. 14, n. 12, p. 1849-1854, 2008. https://doi.org/10.3201/eid1412.080876 